\title{
Cytogenetic and Developmental Effects of Antidepression Drug (Cipralex) on Female Mice and Embryos
}

\author{
Hanaa M. Roshdy \& Thanaa M.T Shoman
}

\author{
Cell Biology Department, National Research Center \\ Dokki, Cairo, Egypt
}

\begin{abstract}
Escitalopram (cipralex $\left.{ }^{\circledR}\right)$ a new highly selective serotonin reuptake inhibitor, it is effective in the treatment of patients with major depression. To evaluate the cytogenetics and developmental effects of cipralex throughout major organgenesis, mice were administrated orally with a doses of $0.06,0.12$ and $0.24 \mathrm{mg} / \mathrm{kg} /$ day cipralex on gestation days $1-18$ and examined on the $19^{\text {th }}$ day of gestation for evidence of maternal and fetal toxicity. Cipralex at different doses tested produce significant toxic effects in reproductive parameters. Significant embryo fetotoxic effects were observed at tested dose levels as evidenced by total number of implantations, post. Implantation loss and embryo malformations. There were increases in the frequencies of micronuclei and chromosomal aberrations in both maternal and embryonic cells treated with cipalex, these increases were dose dependent. These results indicate that cipralex is considered to be cytogenetic and embryo toxic drug when administered during pregnancy.
\end{abstract}

Key words:- Escitalopram - chromosomal aberrations - micronuclei - embryo - mice

\section{Introduction}

Depression is a common and serious disorder, every year, depression affects $10 \%$ of adult humans over age 18 , depression takes a big toll is suffering and can lead to suicidien severe cases. However, scientists do not know the exact mechanism that triggers depressive illness. In the past scientists believed that depression was the result of thoughts or emotions that were troubling for a person. More recently, experts realize that there can be several factors working together that will lead a person to become depressed. The three most important of these are biological, genetic and environmental factors (Croom and Plosker, 2004).

Biological causes are due to the changes in the chemistry of the brain, such as fluctuations in the levels of important hormones.

Genetic causes are the result of what you inherit from your parents, if one or both of parents have a depression, then it can be transmitted to sons. Environmental factors, result from stressful emotional situations, depression can also occur as a result of a combination of the three factors.
Escitalopram (Cipralex), a new highly selective serotonin reuptake inhibitor. It is effective in the treatment of patients with major depressive disorder (Croom and Plosker, 2003). Due to the risk associated with untreated depressive women (Cipralex) therapy is generally continued during pregnancy.

For Escitaloprom (Cipralex) no clinical data are available regarding exposed pregnancies. In rat reproductive toxicity studies performed with Escitalopram, embryo-toxic effects, but no increased incidence of malformations, were observed. So, in the present study we examined the cytogenetics effect of Escitaloprom on pregnant mice and embryos and the fetal developmental toxicity of cipralex given orally to mice during the pregnancy.

\section{Materials and Methods}

\section{Test drug:}

Cipralex $^{\mathrm{R}}$ (Escitalopram oxalate) is sparingly soluble in water slightly soluble in acetone, freely soluble in methanol, its chemical name: $\mathrm{S}(+)-1-\quad$ (3-diem 
ethylaminopropyl) -1-(4-fluoropheny L)1,3-dihydros-ioben zo furan-s-carbonitrile hydrogen oxalate.

\section{Molecular weight:}

$$
\mathrm{C}_{20} \mathrm{H}_{21} \mathrm{FN}_{2} \mathrm{O}_{2} \mathrm{C}_{2} \mathrm{H}_{2} \mathrm{O}_{4} \text { : 414-42 }
$$

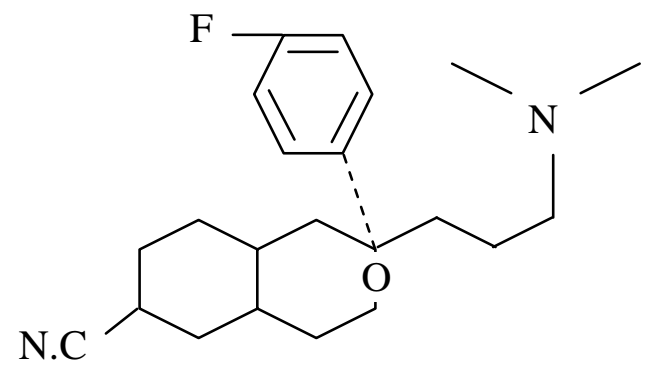

\section{Animals and Treatments:}

Adult fertile males and adult virgin females swiss albino mice each weighting $25 \mathrm{gm}$ were used. The dose of cipralex should be administered a single oral dose of $10 \mathrm{mg} /$ day, depending on individual patient response, the dose may be increased to a maximum of $20 \mathrm{mg}$ daily.

Females were housed in specially designed cages with adult males by ratio 3:1. After one day of mating at $09.00 \mathrm{am}$, the females which exhibiting a vaginal plug the day of the appearance of a vaginal plug was considered as the 1 day of pregnancy. The pregnant feamels were caged individually and divided into three groups each group was injected orally from the day 1 to the day 18 of gestation with a single dose of $(0.06 \mathrm{mg} / \mathrm{kg} /$ day $),(0.12 \mathrm{mg} / \mathrm{kg} /$ day $)$ and $0.24 \mathrm{mg} / \mathrm{kg} / \mathrm{day}$ ) these doses equivaleut to the therapeutic dose, 2 times and 4 times the therapeutic dose 1 respectively. The control group injected with similar doses of water.

Pregnant females were sacrificed by cervical dislocation on the $19^{\text {th }}$ day of gestation bone marrow of the females was collected and part of embryos from each group were randomly selected to study the chromosomal aberrations and micronuclei and the other part of embryos were used to study the skeletal malformations and developmental toxicity.

Fetal developmental toxicity:

Live and dead fetuses on the day $19^{\text {th }}$ of gestation were measured. Part of the live fetuses from each pregnant female were preserved in $95 \%$ ethanol for subsequent skeletal malformations after staining with Alizarins.

\section{Micronucleus tests: (In mothers)}

The animals were sacrificed by cervical dislocation on the $19^{\text {th }}$ day of gestation. Bone marrow smears and staining were done following the method of (Schmid 1975). Briefly, both the femora were removed and the bone marrow was flushed with $1 \%$ sodium citrate solution $\left(20^{\circ} \mathrm{C}\right)$ from a syringe. The bone marrow cells were dispersed by gentle pipetting. The cell pellet was resnspended in a small volume of $5 \%$ fetal calf serum in PBs. A drop of this suspension was smeared in a clean slide, air-dried, fixed in absolute methanol for $15 \mathrm{~min}$ and stained with Giemsa stain.

\section{In Embryos:}

Micronuclei were prepared according to the method by Schmid (1976). Small amount of blood from the tail of embryos was flushed with $1 \%$ sodium citrate solution then the embryonic cells were resuspended in a small volume of 5\% fetal calf serum. A drop of this suspension was smeared in a clean slide, air-dried, fixed with methanol and stained with Giemsa stain. 500 cells per each female and embryo were scored.

\section{Chromosomal preparations:}

\section{1- Bone marrow cells of pregnant females:}

Chromosomes from bone marrow cells were prepared according to the method of (Ford and Hamerton 1956). Bone marrow were collected in T.C.M. 199 culture media and colchicine was added to the tube ( $2 \mathrm{ml}$ of 0.05 colchicine). Then, the cells were incubated at $37^{\circ} \mathrm{C}$ for 90 minutes. After centrifugation, $5 \mathrm{ml}$ of hypotonic solution was added and the pellet suspented and incubated at $37^{\circ} \mathrm{C}$ for 30 minutes. After centrifugation the cells were fixed in freshly prepared 3:1 methylalchol-glacial acetic acid then, two or three drops of cell suspension were dropped on a clean slide 
covered with cold ethanol and the slides were stained with $10 \%$ Giemsa stain.

\section{2- Embryonic cells:}

Chromosomal preparations from embryonic cells were prepared according to Evans et al., (1972). Embryos were selected from each group and placed in $5 \mathrm{ml}$ of T.C.M. 199 media. $2 \mathrm{ml}$ of 0.05 colchicine was added, cells were incubated at $37^{\circ} \mathrm{C}$ for 90 minutes and centrifuged, after centrifugation $5 \mathrm{ml}$ of hypotonic solution of $0.56 \% \mathrm{Kcl}$ were added to the pellet. The cells were resuspended in the hypotonic solution and incubated at $37^{\circ} \mathrm{C}$ for $15 \mathrm{~min}$, $5 \mathrm{ml}$ freshly prepared fixative (3 methyl alchole: 1 glacial acetic acid were added. Two or three drops of the cell suspension were dropped to the surface of cold clean slide, after dryness, they were stained with $5 \%$ Giema stain.

50 metaphase spreads were examined from each female and embryo, Numerical (polyploidy and aneuploidy) and structural (gaps, breaks, deletion rings, end to end and endometosis) aberrations were recorded.

\section{Statistical Analysis:}

The incidences of resorption, skele-tal variation, delayed ossification of fetuses between experimental and control values were calculated non-parametrically using wilcoxon's rank sum test (Siegal, 1956).

The data of chromosomal aberrations in the females and embryos were subjected to analysis of variance (ANOVA) according to snedcor and Cochran (1990). Least significant differences were used compare between means according to Waller and Duncan (1969) at probability 5\%. The data of micronucleus tests were expressed as percentage.

\section{Results}

\section{Developmental toxicity:}

Treatment with cipralex during pregnancy from day 1 to day 18 of gestation induces a dose-related increase in the number of resorptions and in the number of dead embryos compared with the control.

Also, the treatment cause a dose-related reduction in the number of live embryos but the mean fetal weight is not affected by the treatment (Table 1).

In the skeletal malformation the numbers of abnormal embryos were slightly increased in the $(0.06 \mathrm{mg})$ treated group and highly increased in the $(0.12$ and $0.24 \mathrm{mg})$ treated groups compared with the control. The major skeletal malformations are delayed ossification and congenital defects (Table 2).

\section{Micronucleus tests:}

The frequency of micronucleus also increased as a function of the dose, up to high values with treatment with $(0.24 \mathrm{mg})$ Cipralex in both mothers and embryos. The distribution of micronuclei were different between mothers and embryos, in the mothers the majority of cells containing one, two and three micronuclei but in the embryos the majority of cells were containing only one and two micronuclei (Table 3).

\section{Chromosomal aberrations:}

\section{a- (in females)}

Cytogenetic examination (Table 4) showed that the groups of females treated with cipralex $(0.06, \quad 0.12$ and 0.24 $\mathrm{mg} / \mathrm{kg} /$ day) during pregnancy had more frequents of chromosomal aberrations (structural and numerical) than the control group and this increase was dose-related. The most frequent structural chromosomal aberra-tions were chromatid gaps, breaks, centric rings, deletions and endometosis) and the most frequent numerical aberrations were (Aneuploidy and polyploidy).

\section{b- In embryos:}

Cytogenetic examination (Table 5) showed that the groups of embryos treated with cipralex $(0.06, \quad 0.12$ and 0.24 $\mathrm{mg} / \mathrm{kg} /$ day) respectively had significantly increased in the total number of structural and numerical aberrations than the control group. The most frequent structural and numerical aberrations were chromatid gaps, breaks, deletions, fragments, endometosis, aneupl-oidy and polyploidy. When comparing the female groups with the embryo groups. It can be seen that the frequencies of chromosomal aberrations in females were significantly increased than the frequencies of embryonic groups. 
Table (1): Effect of (cipralex) administered on days 1 to 18 of gestation on fertility and offspring development of mice

\begin{tabular}{|l|l|l|l|l|}
\hline \multirow{2}{*}{ Parameters } & \multicolumn{3}{|l|}{ Daily dose (mg/kg/b.w.) } \\
\cline { 2 - 5 } & Control & 0.06 & 0.12 & 0.24 \\
\hline No. of females mated & 25 & 30 & 30 & 30 \\
No. of females pregnant & 23 & 25 & 25 & 25 \\
No. of implantations & 230 & 250 & 200 & 200 \\
No. of resorptions & 5 & 7 & 10 & 12 \\
$\%$ & $2.2 \%$ & $2.8 \%$ & $5 \%$ & $6 \%$ \\
No. of live fetuses & 220 & 233 & 178 & 176 \\
$\%$ & $95.6 \%$ & $93.2 \%$ & $89 \%$ & $88 \%$ \\
No. of dead fetuses & 5 & 10 & 12 & 12 \\
$\%$ & $2.2 \%$ & $4 \%$ & $6 \%$ & $6 \%$ \\
Mean fetal body weight & $3.92 \pm 0.3$ & $3.80 \pm 0.3$ & $3.57 \pm 0.2$ & $3.57 \pm 0.2$ \\
\hline
\end{tabular}

Table (2): Skeletal observations of fetuses from female mice Receiving (cipralex) on days 1-18 of gestation.

\begin{tabular}{|l|l|l|l|l|}
\hline \multirow{2}{*}{ Parameters } & \multicolumn{4}{l|}{ Daily dose (mg/kg/b.w.) } \\
\cline { 2 - 5 } $\begin{array}{l}\text { No. Of normal fetuses/ females } \\
\text { examined }\end{array}$ & Control & 0.06 & 0.12 & 0.24 \\
$\begin{array}{l}\text { No. Of abnormal fetuses/ } \\
\text { females examined }\end{array}$ & 7 & $102 / 25$ & $66 / 25$ & $62 / 25$ \\
$\begin{array}{l}\text { Fetuses with delayed } \\
\text { ossification }\end{array}$ & 4 & 14 & 23 & 26 \\
$\begin{array}{l}\text { Extra ribs } \\
\text { Wavy ribs }\end{array}$ & 1 & 8 & 10 & 12 \\
$\begin{array}{l}\text { No. Of fetuses with congenital } \\
\text { defects }\end{array}$ & 0 & 0 & 3 & 3 \\
Bifid rib & 2 & 4 & 2 & 3 \\
\hline
\end{tabular}

Table (3): Results of micronucleus tests in mothers and embryos after maternal oral administration with (cipralex).

\begin{tabular}{|c|c|c|c|c|c|c|c|}
\hline \multirow[b]{2}{*}{ Mothers } & \multirow[b]{2}{*}{$\begin{array}{l}\text { Dose } \\
\mathrm{mg} / \mathrm{kg} / \mathrm{b} . \mathrm{W}\end{array}$} & \multirow[b]{2}{*}{$\begin{array}{l}\text { Number } \\
\text { of } \\
\text { assessed } \\
\text { PCE }\end{array}$} & \multirow[b]{2}{*}{$\begin{array}{l}\text { Total } \\
\text { No. of } \\
\text { MN }\end{array}$} & \multicolumn{4}{|c|}{ No. of cells with } \\
\hline & & & & $1 \mathrm{MN}$ & $2 \mathrm{MN}$ & $3 \mathrm{MN}$ & $\begin{array}{l}\text { Frequency } \\
\text { of } \\
\text { Micronucle } \\
(\mathrm{MN})\end{array}$ \\
\hline \begin{tabular}{|l|} 
Control \\
Cipralex
\end{tabular} & \begin{tabular}{|l|}
0 \\
0.06 \\
0.12 \\
0.24
\end{tabular} & $\begin{array}{l}500 \\
500 \\
500 \\
500 \\
\end{array}$ & $\begin{array}{l}180 \\
210 \\
240 \\
265\end{array}$ & \begin{tabular}{|l|}
85 \\
90 \\
110 \\
130 \\
\end{tabular} & $\begin{array}{l}65 \\
80 \\
90 \\
95 \\
\end{array}$ & $\begin{array}{l}30 \\
40 \\
40 \\
40 \\
\end{array}$ & $\begin{array}{l}36 \% \\
42 \% \\
48 \% \\
53 \% \\
\end{array}$ \\
\hline Embryos & $\begin{array}{l}\text { Dose } \\
\mathrm{mg} / \mathrm{kg} / \mathrm{b} . \mathrm{w}\end{array}$ & $\begin{array}{l}\text { Number } \\
\text { of } \\
\text { assessed } \\
\text { PCE } \\
\end{array}$ & $\begin{array}{l}\text { Total } \\
\text { No. of } \\
\text { MN }\end{array}$ & $1 \mathrm{MN}$ & $2 \mathrm{MN}$ & $\begin{array}{l}\text { Frequ } \\
\text { of } \\
\text { Micro } \\
(\mathrm{MN}) \\
\end{array}$ & ncy \\
\hline $\begin{array}{l}\text { Control } \\
\text { Cipralex }\end{array}$ & \begin{tabular}{|l|}
0 \\
0.06 \\
0.12 \\
0.24 \\
\end{tabular} & \begin{tabular}{|l}
500 \\
500 \\
500 \\
500 \\
\end{tabular} & $\begin{array}{l}150 \\
170 \\
200 \\
225 \\
\end{array}$ & \begin{tabular}{|l|}
85 \\
90 \\
103 \\
120 \\
\end{tabular} & \begin{tabular}{|l|}
65 \\
80 \\
97 \\
105 \\
\end{tabular} & $\begin{array}{l}30 \% \\
34 \% \\
40 \% \\
45 \% \\
\end{array}$ & \\
\hline
\end{tabular}


Table (4): Effect of (Cipralex) on maternal bone marrow cells.

\begin{tabular}{|c|c|c|c|c|c|c|c|c|c|c|c|}
\hline \multirow{2}{*}{$\begin{array}{l}\text { Dose } \\
\mathrm{Mg} / \mathrm{kg} / \text { day }\end{array}$} & \multicolumn{7}{|c|}{ Structural aberration } & \multirow{2}{*}{$\begin{array}{l}\text { T.S. } \\
\text { A }\end{array}$} & \multicolumn{3}{|c|}{ Numerical aberration } \\
\hline & $\begin{array}{l}\text { Chromatid } \\
\text { gaps }\end{array}$ & \begin{tabular}{|l} 
Chromosomal \\
gaps
\end{tabular} & $\begin{array}{l}\text { Chromatid } \\
\text { breaks }\end{array}$ & \begin{tabular}{|l|} 
Centric \\
rings
\end{tabular} & Deletions & Fragments & Endmitosis & & $\begin{array}{l}\text { Aneu- } \\
\text { ploidy }\end{array}$ & $\begin{array}{l}\text { Poly- } \\
\text { ploidy }\end{array}$ & $\begin{array}{l}\text { T.N. } \\
\text { A }\end{array}$ \\
\hline Control & $4.667^{\mathrm{C}}$ & 1.000 & $2.000^{\mathrm{C}}$ & 1.33 & $2.667^{\mathrm{C}}$ & $3.000^{\mathrm{B}}$ & 4.667 & $19.33^{\mathrm{D}}$ & $7.000^{\mathrm{L}}$ & $3.333^{C}$ & $10.33^{\mathrm{D}}$ \\
\hline \multicolumn{12}{|l|}{ Cipralex } \\
\hline $\begin{array}{l}0.06 \\
\mathrm{mg} / \mathrm{kg} / \mathrm{day}\end{array}$ & $6.667^{\mathrm{B}}$ & 1.333 & $4.000^{\mathrm{B}}$ & 1.000 & $4.667^{\mathrm{B}}$ & $4.000^{\mathrm{AB}}$ & 4.667 & $26.33^{\mathrm{C}}$ & $11.33^{\mathrm{C}}$ & $6.000^{\mathrm{B}}$ & $17.33^{\mathrm{C}}$ \\
\hline $\begin{array}{l}0.12 \\
\mathrm{mg} / \mathrm{kg} / \mathrm{day}\end{array}$ & $9.667^{\mathrm{A}}$ & 1.667 & $5.333^{\mathrm{AB}}$ & 2.333 & $5.000^{\mathrm{AB}}$ & $5.333^{\mathrm{A}}$ & 3.000 & $32.33^{\mathrm{B}}$ & $12.67^{\mathrm{B}}$ & $7.667^{\mathrm{A}}$ & $20.33^{\mathrm{B}}$ \\
\hline $\begin{array}{l}0.24 \\
\mathrm{mg} / \mathrm{kg} / \text { day }\end{array}$ & $8.667^{\mathrm{A}}$ & 2.667 & $6.333^{\mathrm{A}}$ & 2.000 & $6.333^{A}$ & $4.000^{\mathrm{AB}}$ & 5.000 & $35.00^{\mathrm{A}}$ & $15.00^{A}$ & $8.667^{\mathrm{A}}$ & $23.67^{\mathrm{A}}$ \\
\hline
\end{tabular}

Means of different letters (A, B, C, D) in the same column are significantly different. The column without letters in not significant. 50 metaphase cells were examined from each animal.

Table (5): Effect of (Cipralex) maternal treatment on embryos at 19 days of gestations.

\begin{tabular}{|c|c|c|c|c|c|c|c|c|c|c|c|}
\hline \multirow{2}{*}{$\begin{array}{l}\text { Dose } \\
\mathrm{Mg} / \mathrm{kg} / \text { day }\end{array}$} & \multicolumn{7}{|c|}{ Structural aberration } & \multirow{2}{*}{ T.S. } & \multicolumn{3}{|c|}{ Numerical aberration } \\
\hline & $\begin{array}{l}\text { Chromatid } \\
\text { gaps }\end{array}$ & $\begin{array}{l}\text { Chromosomal } \\
\text { gaps }\end{array}$ & $\begin{array}{l}\text { Chromatid } \\
\text { breaks }\end{array}$ & \begin{tabular}{|l|} 
Centric \\
rings
\end{tabular} & Deletions & Fragments & Endmitosis & & $\begin{array}{l}\begin{array}{l}\text { Aneu- } \\
\text { ploidy }\end{array} \\
\end{array}$ & \begin{tabular}{|l|} 
Poly- \\
ploidy
\end{tabular} & $\begin{array}{l}\text { T.N. } \\
\text { A }\end{array}$ \\
\hline Control & $5.667^{\mathrm{C}}$ & 1.333 & $0.333^{\mathrm{C}}$ & $0.000^{\mathrm{C}}$ & $3.000^{\mathrm{C}}$ & 1.667 & 3.000 & $15.000^{\mathrm{D}}$ & $6.000^{\mathrm{C}}$ & $1.000^{\mathrm{C}}$ & $7.000^{\mathrm{D}}$ \\
\hline \multicolumn{12}{|l|}{ Cipralex } \\
\hline $\begin{array}{l}0.06 \\
\mathrm{mg} / \mathrm{kg} / \mathrm{day}\end{array}$ & $5.000^{\mathrm{C}}$ & 2.000 & $3.333^{\mathrm{B}}$ & $0.667^{\mathrm{C}}$ & $3.667^{\mathrm{BC}}$ & 2.667 & 2.333 & $19.667^{\mathrm{C}}$ & $9.667^{\mathrm{B}}$ & $4.667^{\mathrm{B}}$ & $14.333^{\mathrm{C}}$ \\
\hline $\begin{array}{l}0.12 \\
\mathrm{mg} / \mathrm{kg} / \mathrm{day}\end{array}$ & $7.000^{\mathrm{A}}$ & 1.333 & $4.667^{\mathrm{B}}$ & $2.667^{\mathrm{B}}$ & $5.000^{\mathrm{AB}}$ & 2.333 & 2.667 & $25.667^{\mathrm{B}}$ & $11.67^{\mathrm{A}}$ & $5.333^{B}$ & $17.000^{\mathrm{B}}$ \\
\hline $\begin{array}{l}0.24 \\
\mathrm{mg} / \mathrm{kg} / \mathrm{day}\end{array}$ & $6.000^{\mathrm{B}}$ & 3.333 & $6.333^{\mathrm{A}}$ & $3.667^{\mathrm{A}}$ & $6.000^{\mathrm{A}}$ & 1.667 & 3.000 & $30.000^{\mathrm{A}}$ & $12.00^{\mathrm{A}}$ & $7.000^{A}$ & $19.000^{\mathrm{A}}$ \\
\hline
\end{tabular}

Means of different letters (A, B, C, D) in the same column are significantly different. The column without letters in not significant. 50 metaphase cells were examined from each animal.

\section{Discussion}

The present study was carried in order to evaluate the cytogenetic and developmental toxicity of Escitalopram (Cipralex) a new effective drug in the treatment of depressstion disorder, on the pregnant females (mothers) and on their embryos.

A number of reviews concerning the toxicity, carcinogenicity and mutagenicity of Citalopram which is similar to Escitalopram. Citalopram did not show any carcinogeneic activity in long term oral studies using mice and rats at doses up to
$40 \mathrm{mg} / \mathrm{kg} /$ day. In assays of genotoxic activity, Cialopram showed no evidence of mutagenic or clastogenic activity (Croom and Plosker 2004).

The present study showed that administration of a single dose of 0.06 $\mathrm{mg} / \mathrm{kg} /$ day to pregnant female, caused a slight significant increase in the chromosomal aberrations in the maternal bone marrow cells and in the embryonic cells. Also caused skeletal malformations and developmental toxicity in the embryos. 
However, the administration of single dose of $0.12 \mathrm{mg} / \mathrm{kg} /$ day to pregnant mice during gestation period 1 to 18 days produced a highly significant increase in the chromosomal aberrations of the maternal bone marrow cells. Chromosomal aberrations and fetal malformations were observed in embryos on day 19 of gestation. While, in the group of pregnant females that administrated with a single dose of $0.24 \mathrm{mg} / \mathrm{kg}$ during gestation, a very highly significant increases in the chromosomal aberrations of maternal and fetal cells were observed when compared with the other two groups $(0.06$ and 0.12 $\mathrm{mg} / \mathrm{kg}$ ) respectively and controls.

Also the percentages of fetuses affected by skeletal malformations and the percentages of dead fetuses were increased significantly when compared with the other groups and the control.

The percentages of live fetuses and the embryonic weight were decreased signifycantly compared with the control group.

Moreover, the comparative analysis of the frequency of micronuclei in the mice treated with $(0.06,0.12$, and 0.24 $\mathrm{mg} / \mathrm{kg} /$ day) respectively showed that the frequency of micronucleated cells increased significantly in the females and embryos treated groups. These increases were dosedependent.

These results are agreement with (Bendz, 2003) who found that oral treatment of rats with Escitalopram (Cipralex) during organogenesis at maternotoxic doses led to increased postimplantation loss and reduced fetal weight.

On the other hand, negative results had reported by (Croom, and Plosker 2003) who observed that there were no peri (Postnatal effects of Escitalopram following oral dosing of pregnant rats during gestations and no increased in the incidence of malformations observed.

Also, negative results were observed by (Croom and Plosker 2004) the effects of Esictalopram can be directly predicted from Citalopram. Citalopram did not show any mutagenic or clastogenic activity when administered during pregnancy and did not affect the female fertility.

In, conclusion it was observed that Escitalopram (Cipralex) had a slight mutagenic and developmental toxic effects on the mothers and their embryos when administered (in a therapeutic dose $0.06 \mathrm{mg} / \mathrm{kg} / \mathrm{day}$ ) during the pregnancy. In a doses of 0.12 $\mathrm{mg}$ and $0.24 \mathrm{mg} / \mathrm{kg} / \mathrm{day}$ Cipralex had a very significant increases of mutagenic and developmental toxic effects on the mothers and their embryos and caused increase in the incidences of fetal malformations and in the frequency of micronucleated cells, if taken during pregnancy. Therefore, Cipralex should not be used during pregnancy unless clearly necessary and only after careful consideration of the risk/benefit.

\section{References}

1. Bendz, H.: Who does need Cipralex and why?, 2003 Lakartidningen. 99(20): 23202321.

2. Croom, K.F. and Plosker, G.L.: Escitalopram a pharmacoeconomic review of itsusein depression. 2003 Pharmacoeconomics; 21(16): 1185-1199.

3. Croom, K.F. and Plosker, G.L.: Spotlight on pharmacoeconomics of Escitalopram in depression, 2004 drugs; 18(7): 469-37.

4. Evans, E.P.; Burtenshaw, M.D. and Ford, E.C.: Chromosmoes of mouse embryos and newborn young: preparations from membranes and tail tips. 1972 Stain Technol., 47: 229-234.

5. Ford, C.E. and Hamerton, J.L.: Colchicine, hypotonic citrate, squash sequence for mammalian chromosomes stain. 1956 Technol. 13: 103-122.

6. Schmid, W.: The micronucleus tests. 1975 Mut. Res.; 31: 9-15.

7. Schmid, W.: the micronucleus-test for cytogenetic analysis, in: A. Holllaender (Ed.)., Chemical Mutugens, Pricniples and Methods for their detection. 1976 plenum press, New York, London, Vol. 4, pp. 31-53.

8. Siegal, S. Non parametric Statistics for the Behavioural sciences. 1956 Mc Graw-Hill, New York, pp. 116-127.

9. Snedecor, G.W. and Cochran, W.G.: Statistical methods, $9^{\text {th }}$ ed. Lowa Stae Unive 1990. Press, Lova, USA.

10. Waller, A. and Duncan, D.B. Multiple Range and multiple test. 1969 Bionetries, 11: 1-24. 


\section{التأثثر الوراثى والنموى لاواء السيبراليكس المضاد للاكتئاب فى إناث

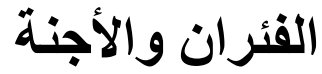

د. هناء محمود رشدى - د. ثناء محمد تهامى شومان

قسم بيولوجيا الخلية المركز القومى للبحوث ــ الأقى ــ القاهرة

يعتبر السبير اليكس دواء جديد وفعـال فى علاج الأشخاص المصابين بالاكتئـاب هذا

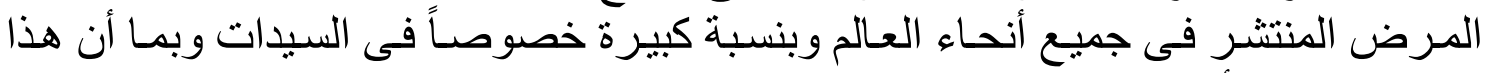

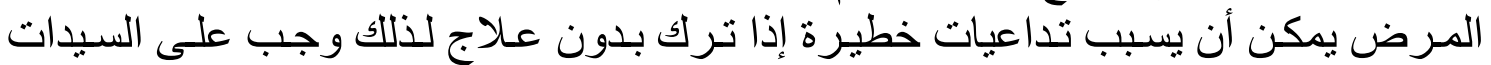

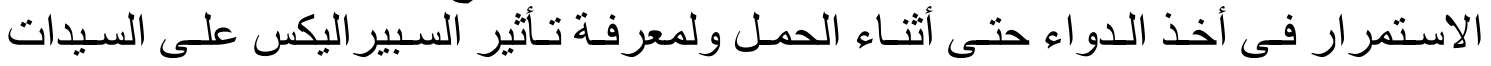

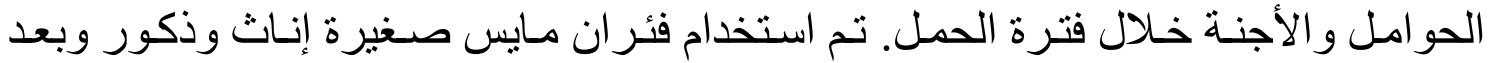

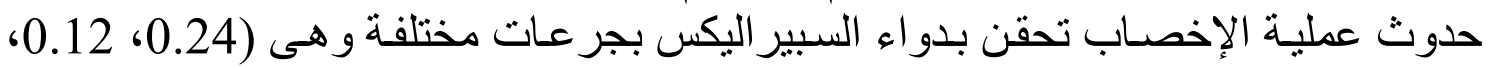

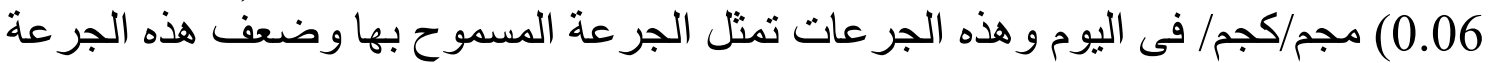

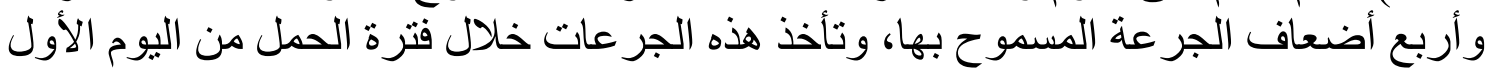

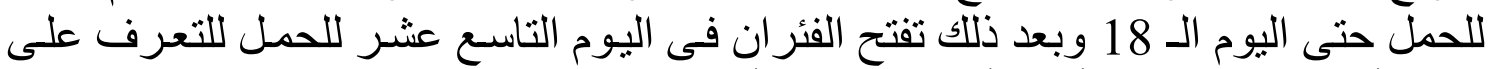

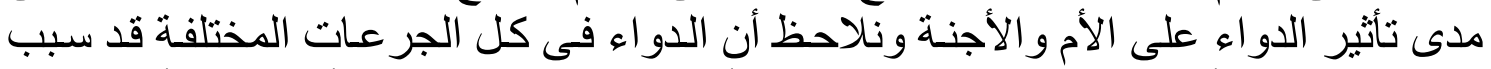

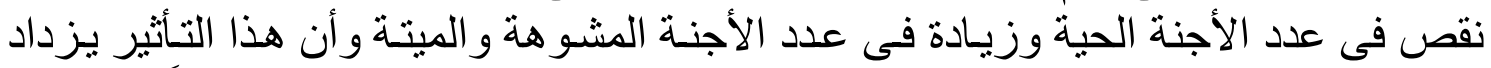

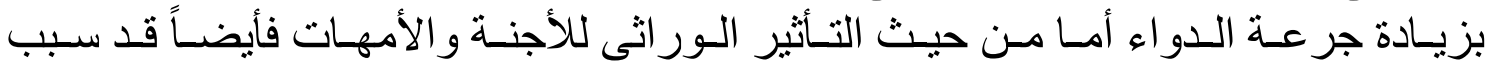

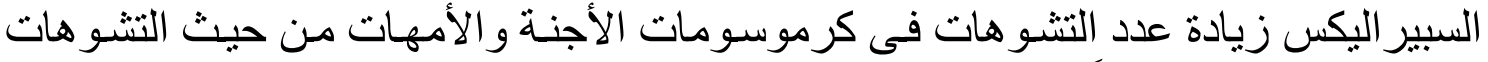

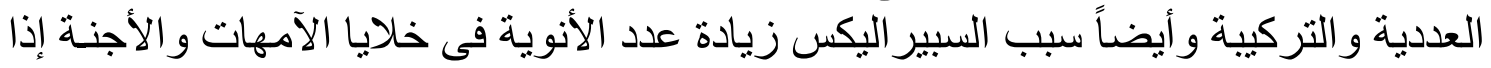

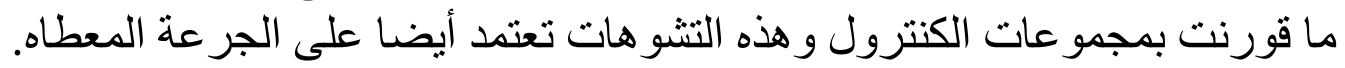

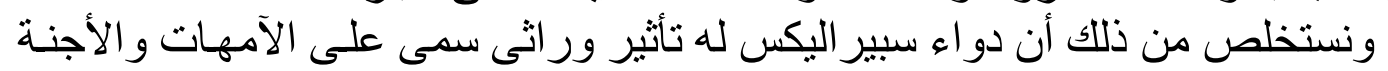

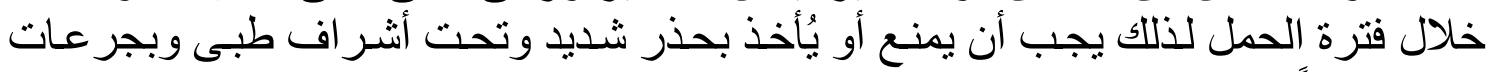

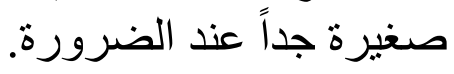

